\title{
ISOTHERMAL IMIDATION KINETICS OF POLYMETHACRYLIMIDE BASED ON IN-SITU FTIR
}

\author{
IZOTERMALNA IMIDACIJSKA KINETIKA POLIMETAKRILIMIDA \\ NA OSNOVI IN SITU FTIR
}

\author{
Jing Zhang ${ }^{1,2 *}$ Xu Ma', Bao-Yu Huang ${ }^{2}$, Song $\mathrm{Lv}^{2}$, Yi-Fan Zhou', \\ Jiao-Xia Zhang ${ }^{1}$ \\ ${ }^{1}$ School of Materials Science and Engineering, Jiangsu University of Science and Technology, Zhenjiang 212003, China \\ ${ }^{2}$ Changzhou Sveck Photovoltaic New Material Co., Ltd, Changzhou 213200, China \\ Prejem rokopisa - received: 2019-03-31; sprejem za objavo - accepted for publication: 2019-07-12
}

doi:10.17222/mit.2019.070

\begin{abstract}
The isothermal imidation process of polymethacrylimide (PMI) prepared from acrylonitrile (AN), methacrylic acid (MAA) and alpha-methylstyrene (AMS) was investigated by "in-situ" Fourier transform infrared spectroscopy (FTIR) at different temperatures, ranged between $180{ }^{\circ} \mathrm{C}$ and $200{ }^{\circ} \mathrm{C}$. The bending vibration absorption peak of hydrogen on the benzene ring in AMS at $700 \mathrm{~cm}^{-1}$ was selected as the internal standard. The extent of the imidation was defined by the area ratio of the characteristic absorption peak of the nitrile groups at $2243 \mathrm{~cm}^{-1}$ to the internal standard. The plots of imidation extent versus time were analyzed by the Friedman method and the Avrami equation. The activation energy at the imidation extent between 0 and 0.2 was $60.4 \mathrm{~kJ} / \mathrm{mol}$ to $65.1 \mathrm{~kJ} / \mathrm{mol}$, which was ascribed to the reaction of the forming imide ring structures. The increase of the activation energy from $65.1 \mathrm{~kJ} / \mathrm{mol}$ to $92.3 \mathrm{~kJ} / \mathrm{mol}$ at the imidation extent between 0.2 and 0.4 can be ascribed to the reaction of forming polyimine cyclic structures. At the imidation extent higher than 0.4 , the activation energy decreased from $92.3 \mathrm{~kJ} / \mathrm{mol}$ to $52.1 \mathrm{~kJ} / \mathrm{mol}$ and the frequency factor $(\ln A)$ fell from $20.5 \mathrm{~s}^{-1}$ to $12.6 \mathrm{~s}^{-1}$. At this stage, the reaction was controlled by diffusion. Moreover, the Avrami curves were in good agreement with the experimental data of the imidation, except for the late stage. The decrease of the kinetic constant from $2.14 \times 10^{4} \mathrm{~s}^{-1}$ to $0.92 \mathrm{~s}^{-1}$ and activation energy from $54.05 \mathrm{~kJ} / \mathrm{mol}$ to $20.39 \mathrm{~kJ} / \mathrm{mol}$ further indicated that the imidation mechanism of the AN/MAA/AMS co-polymer system changed from kinetically controlled at the prophase to diffusion controlled at the anaphase.
\end{abstract}

Keywords: polymethacrylimide, isothermal imidation kinetics, in-situ FTIR

Avtorji članka so raziskovali izotermični imidacijski proces polimetakrilimida (PMI), pripravljenega iz akrilonitrila (AN), metakrilne kisline (MAA) in alfa-metilstirena (AMS) z in situ Fourierjevo transformacijsko infrardečo spektroskopijo (FTIR) y temperaturnem območju med $180{ }^{\circ} \mathrm{C}$ in $200{ }^{\circ} \mathrm{C}$. Za interni standard so izbrali pregibni vibracijski absorpcijski vrh vodika na benzenskem obroču v AMS pri $700 \mathrm{~cm}^{-1}$. Obseg imidacije so definirali z razmerjem med presekom karakterističnih absorpcijskih vrhov nitrilnih skupin pri $2243 \mathrm{~cm}^{-1}$ in internim standardom. Grafični prikaz obsega imidacije v odvisnosti od časa so analizirali s Friedmanovo metodo oziroma Avramijevo enačbo. Aktivacijska energija pri obsegu imidacije med 0 in 0,2 je bila od $60,4 \mathrm{~kJ} / \mathrm{mol}$ do $65,1 \mathrm{~kJ} / \mathrm{mol}$, kar so avtorji pripisali reakciji strukturne tvorbe imidnih obročev. Povečanje aktivacijske energije z $65,1 \mathrm{~kJ} / \mathrm{mol}$ na $92,3 \mathrm{~kJ} / \mathrm{mol}$, pri obsegu imidacije med 0,2 in 0,4 , so pripisali reakciji tvorbe ciklične poli-iminske strukture. Pri obsegu imidacije nad 0,4 se je aktivacijska energija zmanjšala z $92,3 \mathrm{~kJ} / \mathrm{mol} \mathrm{na} 52,1 \mathrm{~kJ} / \mathrm{mol}$ in frekvenčni faktor $(\ln A)$ je padel z $20,5 \mathrm{~s}^{-1}$ na $12,6 \mathrm{~s}^{-1}$. V tem stadiju je reakcijo nadzorovala difuzija. Nadalje so se Avramijeve krivulje dobro ujemale $\mathrm{z}$ eksperimentalnimi rezultati imidacije, razen $\mathrm{v}$ zadnjem stadiju. Zmanjšanje kinetične konstante $\mathrm{z} 2,14 \times 10^{4} \mathrm{~s}^{-1}$ na $0,92 \mathrm{~s}^{-1}$ in aktivacijske energije z $54,05 \mathrm{~kJ} / \mathrm{mol}$ na $20,39 \mathrm{~kJ} / \mathrm{mol}$, je nato pokazalo, da se je imidacijski mehanizem AN/MAA/AMS kopolimernega sistema spremenil iz kinetično kontroliranega v profazi v difuzijsko kontroliranega v anafazi.

Ključne besede: polimetakrilimid, izotermična imidacijska kinetika, in situ FTIR

\section{INTRODUCTION}

PMI foam is a kind of high-performance thermosetting resin developed by Degussa, a German company, in 1972. It is applied widely because of its superior performance, such as $100 \%$ closed cellular structure, high thermal resistance, wide range of density control, and excellent mechanical properties. Up to now, PMI foam has developed over 165 specifications in sandwich structures all over the world, including aerospace, shipping, railcar manufacturing, and radome applications. ${ }^{1,2}$

*Corresponding author's e-mail: zhangjing@just.edu.cn (Jing Zhang)
PMI foam was usually prepared by the heat treatment of block copolymers of methacrylonitrile (MAN) or acrylonitrile (AN) and methacrylic acid (MAA) in the presence of crosslinking agents and foaming agents. 3,4 Great effort has been made to research the preparation methods, properties, cellular structures and applications of PMI. ${ }^{15}$ However, there are few researches about the imidation kinetics of PMI. In order to achieve satisfying mechanical and thermal properties, it is necessary to figure out the imidation mechanism of PMI clearly. In our early work, the isothermal curing of PMI has been studied through dynamic mechanical analysis (DMA). ${ }^{6}$

Fourier transform infrared spectroscopy (FTIR) is a conventional analysis technique employed to study the imidation and curing process. ${ }^{712}$ It has the advantages of 
a high signal-to-noise ratio, fast scanning speed and simple operation. However, FTIR cannot evaluate the imidation process of traditional PMI, because no functional group could be taken as an internal standard. In this paper, AMS was introduced as the third monomer to prepare a new PMI. The benzene ring in AMS didnot participate in the imidation reaction, so that the surface bending vibration absorption peak of hydrogen on the mono-substituted benzene ring at $700 \mathrm{~cm}^{-1}$ could be selected as the internal standard. Moreover, the Friedman isoconversional method and Avrami equation were employed to quantify the isothermal imidation kinetics of the PMI.

\section{EXPERIMENTAL PART}

\subsection{Materials}

AN was supplied by Sinopec QiLu Petrochemical Company (China). MAA was supplied by Sinopharm Chemical Reagent Co. Ltd. (China), while AMS was purchased from Shanghai Macklin Biochemical Co. Ltd. (China). Azobisisobutyronitrile (AIBN), supplied by Shanghai Macklin Biochemical Co. Ltd. (China), was used as the initiator. Acrylamide (AM) supplied by Sinopharm Chemical Reagent Co. Ltd. (China) was used as the crosslinking agent.

\subsection{Preparation of AN/MAA/AMS copolymer board}

The preparation of the MAA/AN/AMS copolymer board was carried out via bulk casting. Firstly, the mixture of $210 \mathrm{~g}$ of AN, $155 \mathrm{~g}$ MAA, $40 \mathrm{~g}$ AMS, $1 \mathrm{~g}$ AIBN, and $11 \mathrm{~g}$ AM was pre-polymerized in a threenecked flask in a water bath at $70{ }^{\circ} \mathrm{C}$ for $100 \mathrm{~min}$. Secondly, the prepolymer with a certain viscosity was poured into a vitreous mould, having dimension of 45.0 $\mathrm{mm} \times 45.0 \mathrm{~mm} \times 10.0 \mathrm{~mm}$. Afterwards, the mould was sunk into the water bath at $60{ }^{\circ} \mathrm{C}$ for $72 \mathrm{~h}$. Finally, a transparent and uniform board of AN/MAA/AMS co-polymer was obtained. The samples for the FTIR test were scraped as a fine powder, having the dimension of 200 mesh from the AN/MAA/AMS copolymer board.

\subsection{Measurement}

The FTIR measurement was performed with a homogenized mixture of sample and potassium bromide. The $\mathrm{KBr}$ spectrum was measured for automatic background subtraction to obtain the background contribution. All the spectra were obtained with a resolution of $4 \mathrm{~cm}^{-1}$ in the wavenumber range from $4000 \mathrm{~cm}^{-1}$ to 400 $\mathrm{cm}^{-1}$, averaging 32 scans, using the FTIR Nicolet iS10 of Thermo Scientific (USA). The samples were placed between two 32-mm-diameter $\mathrm{KBr}$ windows in a temperature-controlled sample holder equipped with an electrical heating jacket that allowed the in-situ FTIR analysis. The FTIR spectra were taken at intervals of 5 $\min$ at $180{ }^{\circ} \mathrm{C}, 185^{\circ} \mathrm{C}, 190{ }^{\circ} \mathrm{C}, 195^{\circ} \mathrm{C}$ and $200{ }^{\circ} \mathrm{C}$ for $4 \mathrm{~h}$.

\section{RESULTS AND DISCUSSION}

\subsection{FTIR spectroscopy data}

Figure 1 shows the FTIR curves of the AN/MAA/AMS co-polymer at $190{ }^{\circ} \mathrm{C}$ during the imidation process. The peak at $700 \mathrm{~cm}^{-1}$ is attributed to the surface bending vibration of the hydrogen on the mono-substituted benzene ring in AMS units. The characteristic absorption peak assigned to nitrile groups appeared at $2243 \mathrm{~cm}^{-1}$, which can be utilized to quantitatively evaluate the imidation behavior of AN/MAA/AMS co-polymer system.

The intensity of the band at $2243 \mathrm{~cm}^{-1}$ decreases with the imidation time significantly, which is ascribed to the decrease of the number of nitrile groups. This is mainly attributed to the reaction of the forming imide ring structures between the adjacent monomeric units of AN and MAA (Scheme 1). ${ }^{5,13}$ Moreover, the reaction of the forming polyimine cyclic structures (ladder polymer) could also consume nitrile groups (Scheme 2). 5,13,14 However, the absorption peak of the nitrile groups does not disappear entirely, which indicates that the isothermal imidation of the AN/MAA/AMS copolymer would not achieve a fully imidation system. ${ }^{15,16}$<smiles>CCCCCCCCCC(C#N)CC(C#N)CC(C)(CC(C)(CC)C(=O)O)C(=O)O</smiles>

Scheme 1<smiles>CCCCCCC(C=N)CC(C=N)CC(C)C=N</smiles>

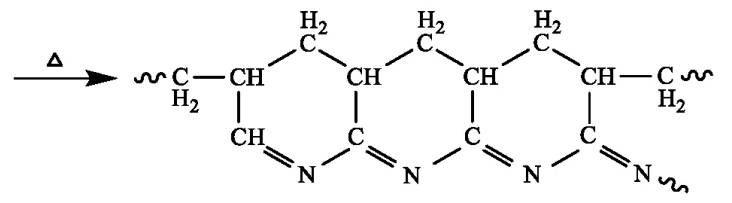

Scheme 2

Furthermore, the absorption peak of the carbonyl groups at $1694 \mathrm{~cm}^{-1}$ splits and the second carbonyl group absorption peak appears at $1630 \mathrm{~cm}^{-1}$, due to the reaction of forming imide ring structures (Scheme 1). ${ }^{13}$ Simult- 
aneously, a new band at $2337 \mathrm{~cm}^{-1}$ is observed, which could be related to the amination reaction of the PAN block that $-\mathrm{NH}_{2}$ was grafted onto the PAN $\left(\mathrm{H}_{2} \mathrm{O}\right.$ was generated from dehydration reaction of adjacent AM). The reaction equation is given in Scheme 3. ${ }^{13,17}$

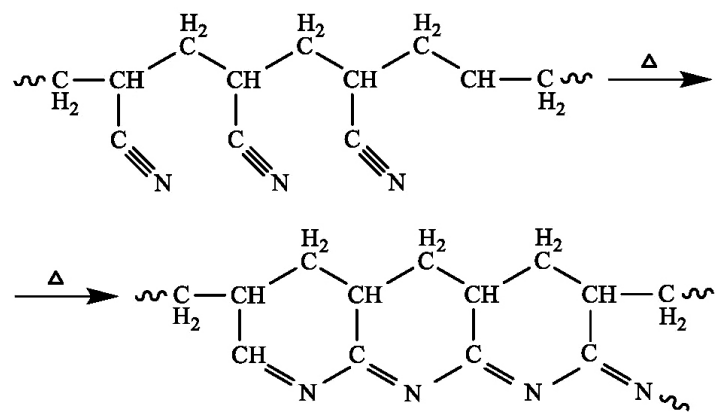

Scheme 3

The extent of the imidation, $\alpha$, is determined quantitatively according to Equation (1):

$$
\alpha=1-\frac{\left(S / S^{*}\right)_{t}}{\left(S / S^{*}\right)_{t=0}}
$$

where $S$ represents the area of characteristic absorption peak of the nitrile group at $2243 \mathrm{~cm}^{-1}$ and $S^{*}$ represents the area of the out-of-plane bending vibration peak of hydrogen on a monosubstituted benzene ring at 700 $\mathrm{cm}^{-1}$. The subscript $t$ denotes the time of the imidation reaction, while $t=0$ means the ratio of the the area at initial time. Figure 2 shows the extent of the imidation $(\alpha)$ versus time $(t)$ curves for the imidation reaction at different temperatures. The conversion achieved 59.30 $\%$ to $61.03 \%$ in $4 \mathrm{~h}$. Figure 3 shows the rate of imidation $(\mathrm{d} \alpha / \mathrm{d} t)$ as a function of the extent of imidation $(\alpha)$ of the AN/MAA/AMS copolymer at different temperatures. The reaction rate was obtained by differentiating the $\alpha-t$ curves. Obviously, there is only

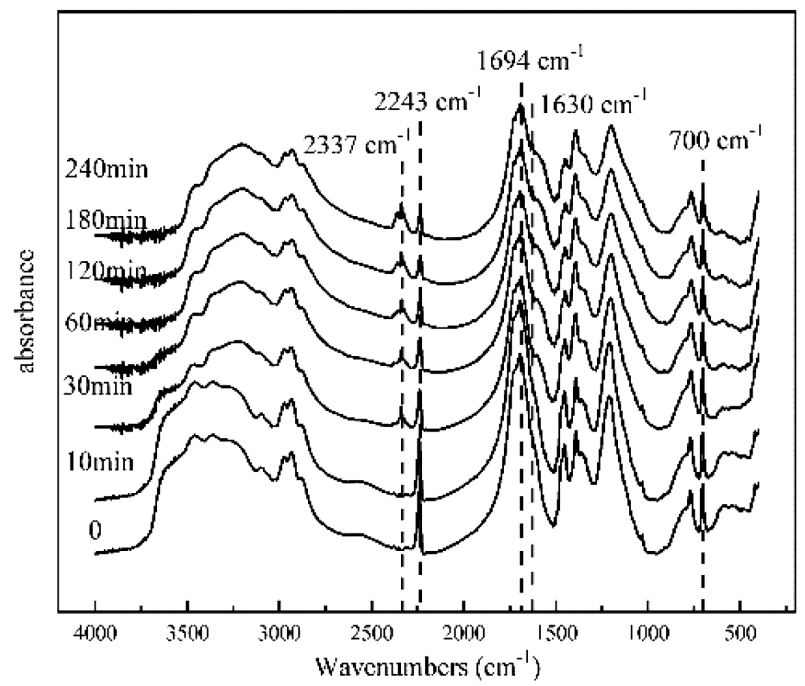

Figure 1: FTIR spectra in the $4000 \mathrm{~cm}^{-1}$ to $400 \mathrm{~cm}^{-1}$ wavenumber range of AN/MAA/AMS copolymer at $190{ }^{\circ} \mathrm{C}$ during the imidation process

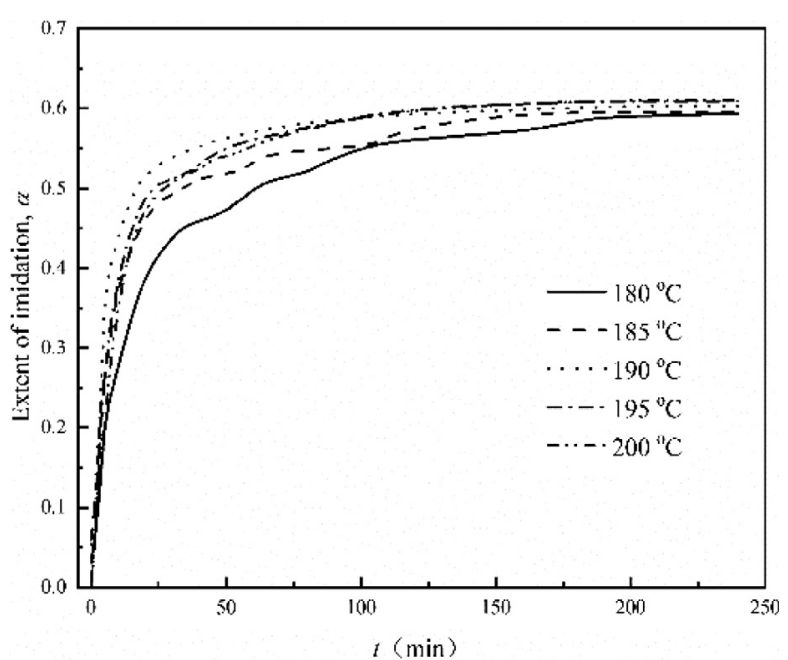

Figure 2: The extent of imidation $(\alpha)$ as a function of time $(t)$ of $\mathrm{AN} /$ MAA/AMS copolymer at different temperatures

one peak on the curves at $180{ }^{\circ} \mathrm{C}$ to $195{ }^{\circ} \mathrm{C}$. The maximum rate of imidation occurs at a certain intermediate extent between 0.1 and 0.2 . Then the reaction rate undergoes a decrease with the increase of extent when $\alpha$ is higher than 0.2 and approaches zero at the end. Interestingly, there are two peaks on the curve at $200{ }^{\circ} \mathrm{C}$. The difference indicates that the imidation mechanism of the AN/MAA/AMS copolymer system changes at temperatures over $200{ }^{\circ} \mathrm{C}$. The second peak can be ascribed to the reaction of forming a ladder polymer between the adjacent $\mathrm{AN}$ monomeric unit (Scheme 2).

\subsection{Model-free study}

The isothermal imidation kinetics of the AN/MAA/AMS copolymer system is described by a

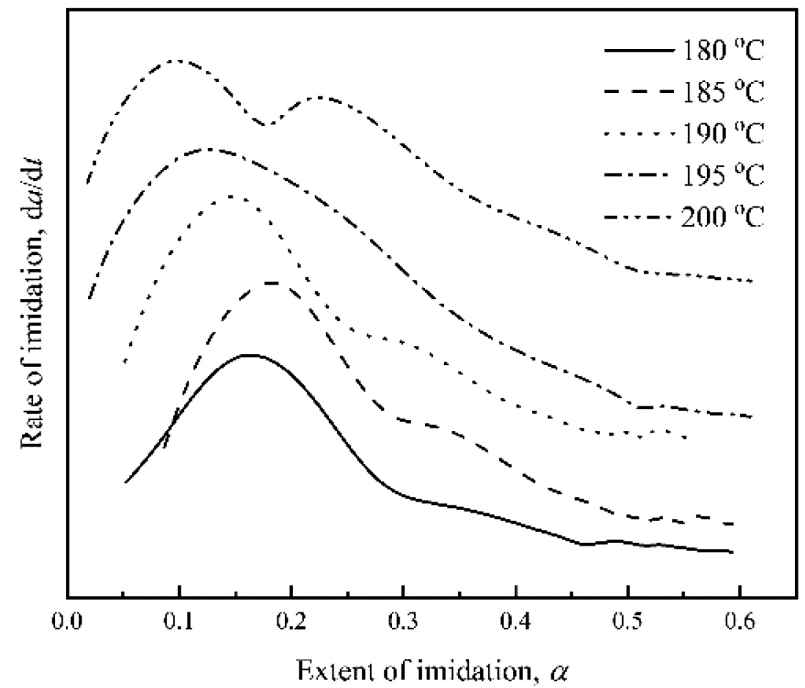

Figure 3: The rate of imidation $(\mathrm{d} \alpha / \mathrm{d} t)$ as a function of extent of imidation $(\alpha)$ of the AN/MAA/AMS copolymer at different temperatures 
general rate equation as a function of temperature and conversion of the imidation, as follows in Equation (2):

$$
\mathrm{d} a / \mathrm{d} t=k(T) f(\alpha)
$$

where $f(\alpha)$ is the kinetic model in accord with the reaction mechanism, and $k$ is the reaction rate constant as a function of temperature $T$ (absolute scale) due to the Arrhenius equation, in Equation (3):

$$
k(T)=A \exp \left(-\frac{E_{\mathrm{a}}}{R T}\right)
$$

where $A$ is the pre-exponential factor (also known as frequency factor, reflecting the number of collisions between functional groups), $E_{\mathrm{a}}$ the activation energy of the imidation reaction and $R$ is the universal gas constant $(8.314 \mathrm{~J} / \mathrm{mol} \cdot \mathrm{K})$. Substituting Equation (3) into the Equation (2) can yield a new expression as:

$$
\mathrm{d} a / \mathrm{d} t=A \exp \left(-\frac{E_{\mathrm{a}}}{R T}\right) f(\alpha)
$$

Then, applying logarithmic properties to two sides of Equation (4), the classical form of the Friedman equation about $E_{\mathrm{a}}$ and $\alpha$ can be obtained, as: ${ }^{18}$

$$
\ln \left(\frac{\mathrm{d} a}{\mathrm{~d} t}\right)=\ln [A f(\alpha)]-\frac{E_{\mathrm{a}}}{R T}
$$

with the assumption that both the activation energy and the pre-exponential factor are the functions of the imidation extent, the significance of the Friedman isoconversional method is that no knowledge of the reaction model and the kinetic rate expression are assumed for the data evaluation. ${ }^{19}$ It is a typical way to describe variations in the curing or imidation kinetics of many thermosetting systems. The activation energy is determined from the slope of the plot of $\ln (\mathrm{d} \alpha / \mathrm{d} t)$ versus $1 / T$ when $\alpha$ takes a constant value. For the $n^{\text {th }}$-order reaction, the value of $\ln A$ can be obtained from the known values of $\ln (\mathrm{d} \alpha / \mathrm{d} t)$ and $E_{\mathrm{a}} / R T$ from Equation (6). ${ }^{19-21}$

$$
\ln [A f(\alpha)]=\ln \left(\frac{\mathrm{d} a}{\mathrm{~d} t}\right)+\frac{E_{\mathrm{a}}}{R T}=\ln A+n \ln f(\alpha)
$$

Figure 4 exhibits the Friedman plots of the isothermal imidation process in the $\alpha$ range between 0.1 and 0.5 by Equation (5). The difference of $\alpha$ value is 0.05 . Figure 5 shows the variation of the activation energy and the pre-exponential factor obtained by the Friedman method at various extent of imidation. For the AN/MAA/AMS copolymer system, the imidation process underwent a rearrangement of the molecular segments, and then the imide ring structure generated between the adjacent acid and the nitrile units (Scheme 1). It has been reported that the cyclization reaction takes place at a temperature of about $150{ }^{\circ} \mathrm{C} .5$ The value of $E_{a}$ increases from $60.4 \mathrm{~kJ} / \mathrm{mol}$ to $65.1 \mathrm{~kJ} / \mathrm{mol}$ slowly at the extent lower than 0.2 is a vivid evidence. At a higher extent of imidation ( $\alpha$ range between 0.2 and 0.4 ), the

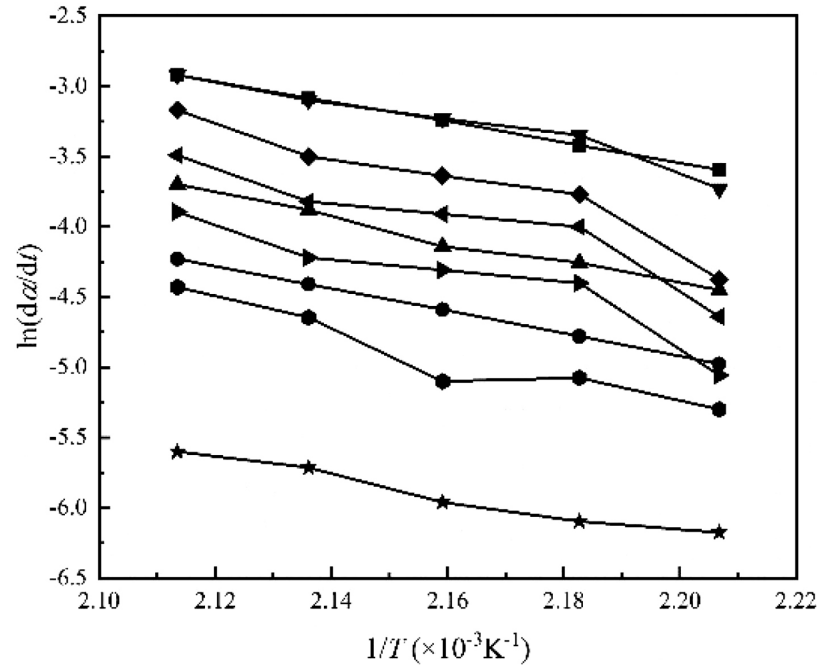

Figure 4: Friedman plots of isothermal imidation process of AN/MAA/AMS copolymer system in the interval $0.1=\alpha=0.5$ (the difference of $\alpha$ value is 0.05 )

activation energy increased from $65.1 \mathrm{~kJ} / \mathrm{mol}$ to $92.3 \mathrm{~kJ} / \mathrm{mol}$. Due to the carboxyl groups adjacent to the nitrile groups have been exhausted, the intermolecular cross-linking of the AN can form a ladder polymer (Scheme 2). The AN monomeric units in copolymer system form ladder polymer structures at high temperatures over $200{ }^{\circ} \mathrm{C} .{ }^{5}$ As for the stage that $\alpha$ is higher than 0.4 , it is noteworthy that the frequency factor decreased quite steeply (Figure 5) The mobility of the unreacted nitrile groups is hindered due to the significant increase of the imidation extent and the crosslinking degree. Moreover, the steric hindrance of the benzene ring in the third monomer AMS restricts the motion of the PMI chain segments. The imidation in the late stage is difficult to take place, and the reaction is controlled by diffusion rather than chemical factors.

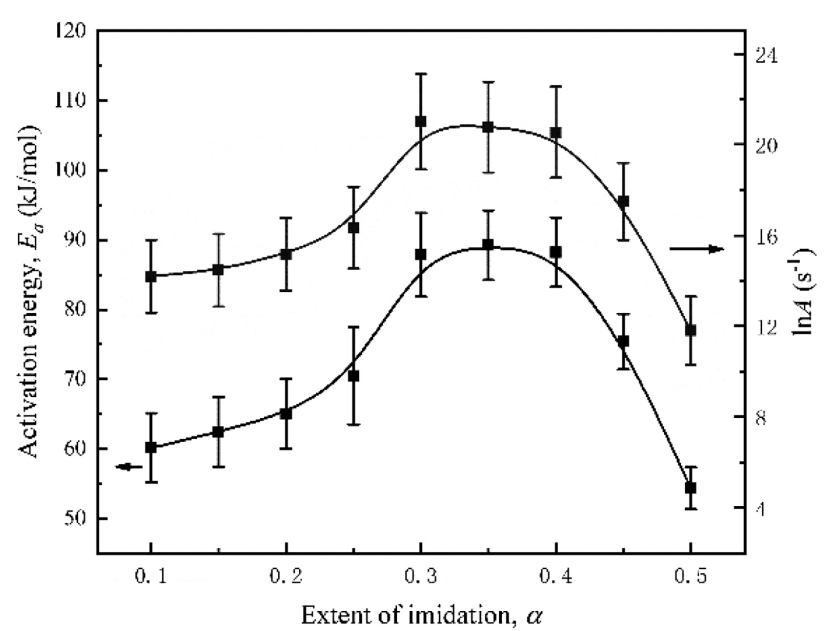

Figure 5: Plots of activation energy $\left(E_{\mathrm{a}}\right)$ and frequency factor $(\ln A)$ of AN/MAA/AMS copolymer system against the extent of imidation $(\alpha)$ obtained by Friedman method 


\subsection{Model-fitting study}

The Avrami equation is an alternative approach to evaluate the activation energy of the imidation reaction of the AN/MAA/AMS copolymer system, which has been applied to analyze the curing of PMI in our previous work. ${ }^{6}$ The classical form of the Avrami equation can be expressed as Equation (7): ${ }^{22}$

$$
1-\alpha=\exp \left[-k_{0} t^{n}\right]
$$

where $k_{0}$ is the kinetic constant related with the temperature and $n$ is the Avrami exponent reflecting the growth mechanism. Applying logarithmic properties to both sides of Equation (7), the following Equation (8) can be obtained.

$$
\ln [-\ln (1-\alpha)]=\ln k_{0}+n \ln t
$$

The kinetic parameters can be calculated from the curves by using the modified Avrami equation. Figure 6 shows the $\ln [-\ln (1-\alpha)]$ versus $\ln t$ curves of AN/MAA/ AMS co-polymer system at different temperatures obtained by Equation (8). According to the difference of slope, each curve in Figure 6 can be divided into two segments. Therefore, the linear fitting should be carried out for each segment independently. The kinetic parameters obtained by the Avrami equation are listed in Table 1. The difference of the Avrami exponent values at different temperatures indicates that the reaction mechanism changes during the imidation process.

Table 1: Fitting results to the Avrami exponent $(n)$ and kinetic constant $\left(k_{0}\right)$ of AN/MAA/AMS copolymer system at different temperatures

\begin{tabular}{|c|c|c|c|c|c|}
\hline$T /{ }^{\circ} \mathrm{C}$ & 180 & 185 & 190 & 195 & 200 \\
\hline$n_{1}$ & 0.616 & 0.511 & 0.340 & 0.494 & 0.743 \\
\hline$k_{0,1}$ & 0.078 & 0.138 & 0.268 & 0.155 & 0.078 \\
\hline$n_{2}$ & 0.275 & 0.192 & 0.122 & 0.160 & 0.191 \\
\hline$k_{0,2}$ & 0.222 & 0.352 & 0.518 & 0.425 & 0.368 \\
\hline
\end{tabular}

Note: the subscripts 1 and 2 denote segments 1 and 2 in Figure 6

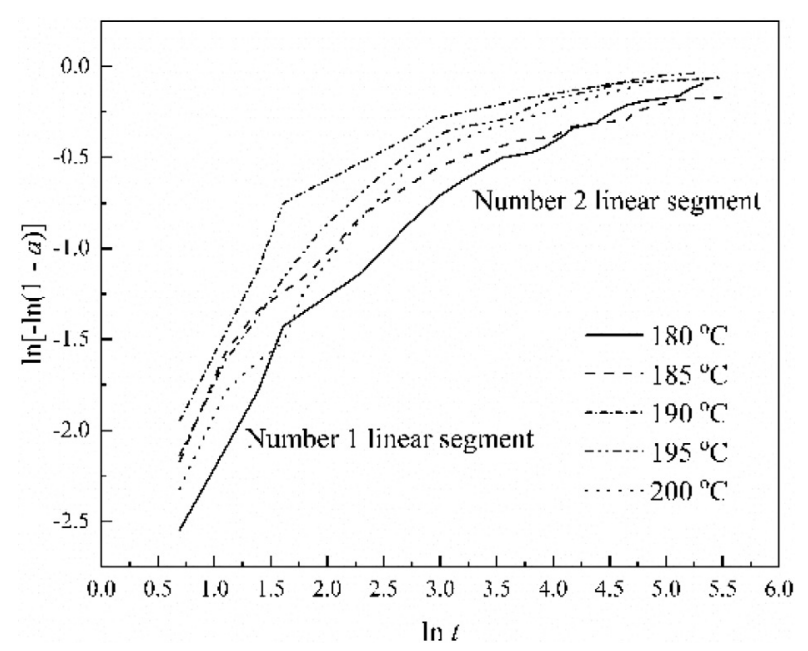

Figure 6: The $\ln [-\ln (1-\alpha)]$ versus $\ln t$ curves of AN/MAA/AMS copolymer system at different temperatures
The curves derived by Equation (6) are compared with the experimentally measured data in Figure 7. Obviously, the modelled curves are in good agreement with the experimental data. While the final degree of fitting shows a poor prediction between $57 \%$ and $60 \%$ conversion. It has been reported that the experimental extent of the imidation was lower than the value calculated by the kinetic model when the reaction became diffusion controlled for a higher extent. ${ }^{23}$ As shown in Figure 7, it became evident that the consideration of the diffusion control in the Avrami model allowed an improved curve description at the latter stage of the imidation.

The correlation between the kinetic constant $\left(k_{0}\right)$ and temperature $(T)$ can be shown as the following empirical Equation (9): ${ }^{24}$

$$
k_{0}^{1 / n}=A \exp \left(-\frac{E_{\mathrm{a}}}{R T}\right)
$$

Applying the logarithmic properties to both sides of Equation (9), the modified Equation (10) can be obtained, from which the value of $E_{a}$ and $k$ can be calculated from the slope and intercept of the fitting curve, respectively:

$$
\frac{1}{n} \ln k_{0}=\ln k-\frac{E_{\mathrm{a}}}{R T}
$$

Figure 8 shows the $(1 / n) \ln k_{0}$ versus $1 / T$ relationship for the linear segments of the $\ln [-\ln (1-\alpha)]-\ln t$ curves. The kinetic constant $(k)$ and activation energy $\left(E_{\mathrm{a}}\right)$ calculated by Equation (10) are listed in Table 2. In the temperature range $180{ }^{\circ} \mathrm{C}$ to $200{ }^{\circ} \mathrm{C}$, the value of the kinetic constant decreased from $2.14 \times 10^{4} \mathrm{~s}^{-1}$ to $0.92 \mathrm{~s}^{-1}$. The four magnitude orders difference indicated that the imidation of AN/MAA/AMS copolymer system was dominated by a kinetic-controlled reaction in the early stage. While the difusion control became operative with the reaction process and the $E_{\mathrm{a}}$ value decreased from

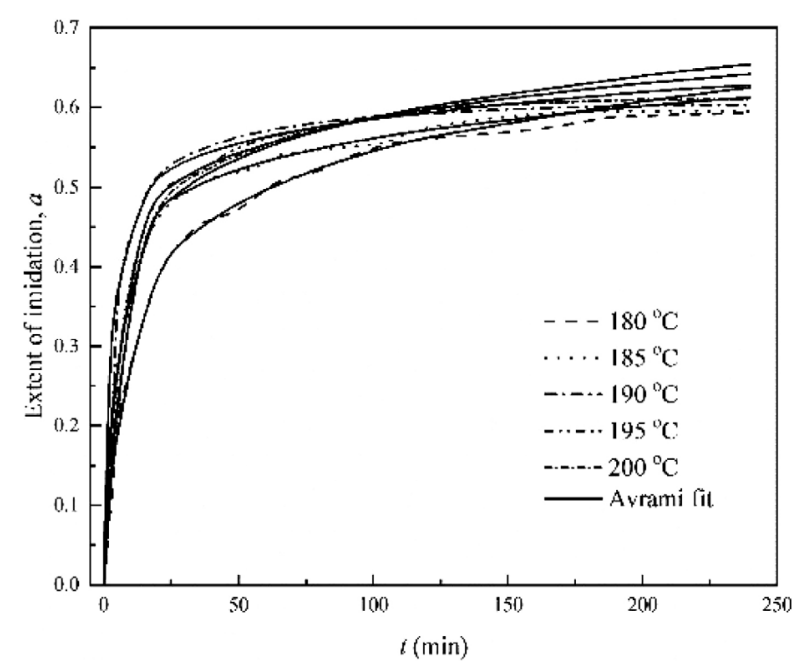

Figure 7: Fitting results of isothermal conversion curves of PMI calculated through the Avrami equation 


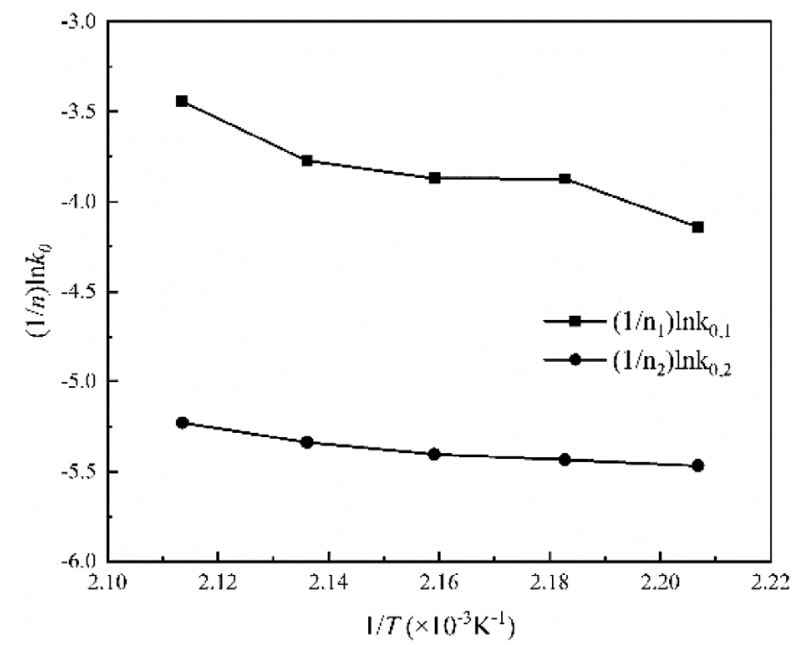

Figure 8: $(1 / n) \ln k_{0}-1 / T$ relationship for the linear segments of the $\ln [-\ln (1-\alpha)]-\ln t$ curves of PMI

$54.05 \mathrm{~kJ} / \mathrm{mol}$ to $20.39 \mathrm{~kJ} / \mathrm{mol}$. This result is consistent with the conclusion from the Friedman method. The results are in agreement with a previous study that the activation energy of the thermosetting system would decrease after becoming diffusion controlled..$^{25,26}$

Table 2: Activation energy of the evolution of $\alpha$ during the imidation process of PMI by Avrami equation

\begin{tabular}{|c|c|c|c|c|}
\hline$T /{ }^{\circ} \mathrm{C}$ & $k_{1} / \mathrm{s}^{-1}$ & $\begin{array}{c}E_{1} \\
/\left(\mathrm{kJ} \cdot \mathrm{mol}^{-1}\right)\end{array}$ & $k_{2} / \mathrm{s}^{-1}$ & $\begin{array}{c}E_{2} \\
/\left(\mathrm{kJ} \cdot \mathrm{mol}^{-1}\right)\end{array}$ \\
\hline $180 \sim 200$ & $2.14 \times 10^{4}$ & 54.05 & 0.92 & 20.39 \\
\hline
\end{tabular}

Note: the subscripts 1 and 2 denote segments 1 and 2 in Figure 6

\section{CONCLUSIONS}

The isothermal imidation process of the AN/MAA/ AMS co-polymer system was investigated by in-situ FTIR at $180{ }^{\circ} \mathrm{C}, 185^{\circ} \mathrm{C}, 190{ }^{\circ} \mathrm{C}, 195^{\circ} \mathrm{C}$ and $200{ }^{\circ} \mathrm{C}$. The bending vibration absorption peak of hydrogen on the mono-substituted benzene ring was selected as the internal standard. The extent of the imidation was defined by the area ratio of the characteristic absorption peak of the nitrile groups to the internal standard. At the imidation extent between 0 and 0.2 , the activation energy was $60.4 \mathrm{~kJ} / \mathrm{mol}$ to $65.1 \mathrm{~kJ} / \mathrm{mol}$, which was ascribed to the reaction of forming imide ring structures between adjacent AM and MAA. The increase of the activation energy from $65.1 \mathrm{~kJ} / \mathrm{mol}$ to $92.3 \mathrm{~kJ} / \mathrm{mol}$ at the imidation extent between 0.2 and 0.4 could be ascribed to the reaction of polyimine cyclic structures between adjacent AN. At the imidation extent higher than 0.4, the activation energy and the frequency factor decreased steeply, and the reaction rate approached zero. At this stage, the imidation of the AN/MAA/AMS co-polymer was controlled by diffusion. Moreover, the predicted curves from the Avrani models fitted well with the experimental data, except for the late stage of the reaction. The decrease of the kinetic constant from
$2.14 \times 10^{4} \mathrm{~s}^{-1}$ to $0.92 \mathrm{~s}^{-1}$ and activation energy from $54.05 \mathrm{~kJ} / \mathrm{mol}$ to $20.39 \mathrm{~kJ} / \mathrm{mol}$ further indicated that the imidation of the AN/MAA/AMS copolymer system was dominated by a kinetic-controlled reaction in the early stage, and the diffusion control became operative in the later stage.

\section{Acknowledgement}

This work was supported by the National Natural Science Foundation of China (Grant No. 51603094), and the Natural Science Foundation of Jiangsu Province (Grant No. BK20160562).

\section{REFERENCES}

${ }^{1}$ H. F. Seibert, PMI foam cores find further applications, Reinforced Plastics, 44 (2000) 36-38, doi:10.1016/S0034-3617(00)86485-1

${ }^{2}$ H. F. Seibert, Applications for PMI foams in aerospace sandwich structures, Reinforced Plastics, 50 (2006) 44-48, doi:10.1016/ s0034-3617(06)70873-6

${ }^{3}$ P. V. Kornienko, Y. P. Gorelov, K. V. Shirshin, Preparation of foamed polymethacrylimide structural materials from cross-linked copolymers of acrylonitrile and methacyrlic acid, Russian Journal of Applied Chemistry, 85 (2012) 1748-1752, doi:10.1134/ s1070427212110195

${ }^{4}$ P. Stein, H. Seibert, L. Maier, R. Zimmermann, W. Heberer,W. Geyer, Method for producing polymethacrylimide foams, (2003)

${ }^{5}$ C. Ting, Z. Guangcheng, Z. Xihao, Structure and properties of AN/MAA/AM copolymer foam plastics, Journal of Polymer Research, 17 (2009) 171-181, doi:10.1007/s10965-009-9303-x

${ }^{6}$ J. Zhang, R. Ye, J. Zou, J. Tang, H. Wang, A study of isothermal curing of PMI using DMA, Advances in Materials Science and Engineering, 2015 (2015) 1-12, doi:10.1155/2015/695286

${ }^{7}$ M. W. Wang, C. T. Lee, M. S. Lin, Curing behaviour of compatible interpenetrating polymer networks based on epoxy and methacrylated epoxy, Polymer International, 44 (2015) 503-509

${ }^{8}$ H. Liu, G. George, Determination of thermal cure kinetics of thin films of photocatalysed dicyanate ester by FTIR emission spectroscopy, Polymer International, 49 (2015) 1505-1512

${ }^{9}$ L. W. Wang, G. F. Fernando, Cure monitoring of epoxy resin by simultaneous DSC/FTIR, Advanced Materials Research, 881-883 (2014) 905-908, doi:10.4028/www.scientific.net/AMR.881-883.905

${ }^{10}$ A. Romo-Uribe, J. A. Arcos-Casarrubias, A. Flores, C. ValerioCárdenas, A. E. González, Influence of rubber on the curing kinetics of DGEBA epoxy and the effect on the morphology and hardness of the composites, Polymer Bulletin, 71 (2014) 1241-1262, doi:10.1007/s00289-014-1121-6

${ }^{11}$ D. S. Achilias, M. M. Karabela, E. A. Varkopoulou, I. D. Sideridou, Cure kinetics study of two epoxy systems with fourier tranform infrared spectroscopy (FTIR) and differential scanning calorimetry (DSC), Journal of Macromolecular Science, Part A, 49 (2012) 630-638, doi:10.1080/10601325.2012.696995

${ }^{12}$ B. Chen, J. Tang, G. Zhang, S. Chen, J. Zhang, Properties and morphologies of epoxy resin based composites reinforced by polyurethane and graphene oxide, Materials Transactions, 58 (2017) 842-844, doi:10.2320/matertrans.M2016464

${ }^{13}$ L. Tie-Min, Z. Guang-Cheng, C. Ting, S. Xue-Tao, Z. Cui, Mechanical properties of methacylic acid/acrylonitrile copolymer foam, Polymer Engineering \& Science, 47 (2007) 314-322, doi:10.1002/pen.20710

${ }^{14}$ S. Dalton, F. Heatley, P. M. Budd, Thermal stabilization of polyacrylonitrile fibres, Polymer, 40 (1999) 5531-5543, doi:10.1016/ S0032-3861(98)00778-2 


\section{J. ZHANG et al.: ISOTHERMAL IMIDATION KINETICS OF POLYMETHACRYLIMIDE BASED ON IN-SITU FTIR}

${ }^{15}$ S. M. Cakić, I. S. Ristić, V. M. Jašo, R. Ž. Radičević, O. Z. Ilić,J. K. Simendić, Investigation of the curing kinetics of alkyd-melamine-epoxy resin system, Progress in Organic Coatings, 73 (2012) 415-424, doi:10.1016/j.porgcoat.2011.03.016

${ }^{16}$ C. Monteserín, M. Blanco, E. Aranzabe, A. Aranzabe,J. Vilas, Effects of graphene oxide and chemically reduced graphene oxide on the curing kinetics of epoxy amine composites, Journal of Applied Polymer Science, 134 (2017), doi:10.1002/app.44803

${ }^{17}$ G. Xu, J. Cao, Y. Zhao, L. Zheng, M. Tao,W. Zhang, Phosphorylated polyacrylonitrile fibers as an efficient and greener acetalization catalyst, Chemistry-An Asian Journal, 12 (2017) 2565-2575, doi:10.1002/asia.201700846

${ }^{18} \mathrm{~S}$. Vyazovkin, Evaluation of activation energy of thermally stimulated solid-state reactions under arbitrary variation of temperature, Journal of Computational Chemistry, 18 (1997) 393-402

${ }^{19}$ J. D. Thanki, P. H. Parsania, Dynamic DSC curing kinetics and thermogravimetric study of epoxy resin of 9, 9'-bis (4-hydroxyphenyl) anthrone-10, Journal of Thermal Analysis and Calorimetry, 130 (2017) 2145-2156, doi:10.1007/s10973-017-6761-y

${ }^{20}$ Y. Lu, M. Li, L. Ke, D. Hu, W. Xu, Curing kinetics of fluorene containing benzoxazine investigated by nonisothermal differential scanning calorimetry, Journal of applied polymer science, 121 (2011) 2481-2487, doi:10.1002/app.33958

${ }^{21}$ J. Zhang, K. Chen, S. Lv, Y. Zhou, X. Ma, J. Tang, Synergistic Effect of Graphene Oxide and OH-MWCNTs on the Cure Kinetics of an
Epoxy-Anhydride System, Materials Transactions, 60 (2019) 616-619, doi:10.2320/matertrans.M2018377

${ }^{22}$ M. G. Lu, M. J. Shim,S. W. Kim, Dynamic DSC Characterization of Epoxy Resin by Means of the Avrami Equation, Journal of Thermal Analysis \& Calorimetry, 58 (1999) 701-709, doi:10.1023/ A: 1010177116739

${ }^{23}$ A. L. Daniel-da-Silva, J. C. M. Bordado,J. M. Martín-Martínez, Moisture curing kinetics of isocyanate ended urethane quasiprepolymers monitored by IR spectroscopy and DSC, Journal of applied polymer science, 107 (2008) 700-709, doi:10.1002/ app. 26453

${ }^{24}$ Y. Yao, D. Chen, P. He,H. Yang, Cure behavior of epoxy resin/CdS/2,4-EMI nanocomposites investigated by dynamic torsional vibration method (DTVM), Polymer Bulletin, 57 (2006) 219-230, doi:10.1007/s00289-006-0550-2

${ }^{25}$ H. S. Y. Hsich, Kinetic model of cure reaction and filler effect, Journal of Applied Polymer Science, 27 (1982) 3265-3277, doi:10.1002/app.1982.070270907

${ }^{26}$ J. Zhang, P. Li, Z. Zhang, X. Wang, J. Tang, H. Liu, Q. Shao, T. Ding, A. Umar,Z. Guo, Solvent-free graphene liquids: promising candidates for lubricants without the base oil, Journal of Colloid and Interface Science, (2019), doi:10.1016/j.jcis.2019.01.135 